\title{
Mechanism of Ferric Chloride Facilitating Efficient Lithium Extraction from Magnesium-Rich Brine with Tri-n-butyl Phosphate
}

\author{
Zheng $\mathrm{Li}^{*}$ and Koen Binnemans
}

Cite This: Ind. Eng. Chem. Res. 2021, 60, 8538-8547

Read Online

ABSTRACT: The synergistic solvent extraction system comprising tri- $n$-butyl phosphate (TBP) and $\mathrm{FeCl}_{3}$ has been intensively studied for selective extraction of $\mathrm{Li}(\mathrm{I})$ from $\mathrm{Mg}(\mathrm{II})$-rich brine. The extraction occurs via the formation of an ion-pair complex $\left[\mathrm{Li}(\mathrm{TBP})_{x}\right]\left[\mathrm{FeCl}_{4}\right]$ in which the negatively charged $\left[\mathrm{FeCl}_{4}\right]^{-}$ neutralizes the positively charged $\left[\mathrm{Li}(\mathrm{TBP})_{x}\right]^{+}$. Counterintuitively, many other metal chlorides give much lower $\mathrm{Li}(\mathrm{I})$ extraction efficiency than $\mathrm{FeCl}_{3}$, although they can also form chlorometallate anions similar to $\left[\mathrm{FeCl}_{4}\right]^{-}$. In this study, the capabilities of $\mathrm{CuCl}_{2}$, $\mathrm{AlCl}_{3}, \mathrm{InCl}_{3}$, and $\mathrm{SnCl}_{4}$ for $\mathrm{Li}(\mathrm{I})$ extraction with TBP were examined and compared with that of $\mathrm{FeCl}_{3}$, accompanied by speciation studies. It was found that (1) $\mathrm{AlCl}_{3}$ does not form

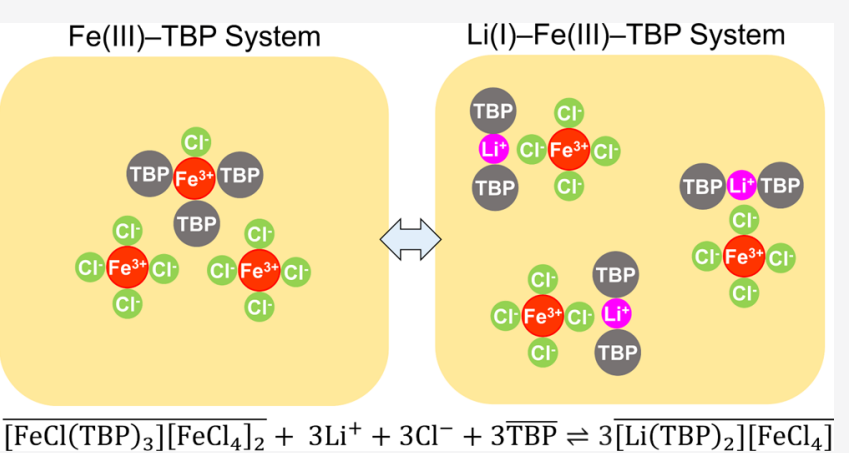
$\left[\mathrm{AlCl}_{4}\right]^{-}$while other metal chlorides $\left(\mathrm{CuCl}_{2}, \mathrm{InCl}_{3}, \mathrm{FeCl}_{3}\right.$, and $\left.\mathrm{SnCl}_{4}\right)$ can form chlorometallate anions that could facilitate $\mathrm{Li}(\mathrm{I})$ extraction and (2) $\mathrm{CuCl}_{2}, \mathrm{InCl}_{3}$, and $\mathrm{SnCl}_{4}$ form neutral solvation complexes with TBP strongly, which hinders the formation of chlorometallate anions, but $\mathrm{FeCl}_{3}$ does not form neutral complexes with TBP. Concurrently being able to form [FeCl$]^{-}$and to avoid forming neutral complexes facilitates the efficient $\mathrm{Li}(\mathrm{I})$ extraction by $\mathrm{FeCl}_{3}$ with $\mathrm{TBP}$.

\section{INTRODUCTION}

Lithium is a versatile element that finds a wide range of applications, among which its use in lithium-ion batteries is particularly important, thanks to its favorable chemical properties. ${ }^{1}$ With the approach of the era of electric vehicles, the global demand for lithium has been increasing, ${ }^{2,3}$ and it is predicted to continue to significantly increase in the next 3 decades. ${ }^{4,5}$ The demand for lithium in 2050 is estimated to be about 5 times that in 2018. ${ }^{5}$ Hard rocks (e.g., spodumene) and salt lake brine are the two main sources of lithium, and $>70 \%$ of the exploitable lithium is found in salt lake brine. ${ }^{6-8}$ Currently, more than half of $\mathrm{Li}_{2} \mathrm{CO}_{3}$ (or equivalent) is produced from brine. The production cost of $\mathrm{Li}_{2} \mathrm{CO}_{3}$ from brine is lower than from hard rocks because brine is already in the liquid state, shortening the process route. ${ }^{6,9}$

Salt lake brine generally contains $\mathrm{Mg}$ (II), and the separation of $\mathrm{Li}(\mathrm{I})$ from $\mathrm{Mg}$ (II) is an essential step in the production of $\mathrm{Li}_{2} \mathrm{CO}_{3}$ from brine. The $\mathrm{Mg}(\mathrm{II}) / \mathrm{Li}(\mathrm{I})$ ratio is a key factor in determining whether and how brine can be mined for lithium. In general, brine in South America has relatively low $\mathrm{Mg}(\mathrm{II}) / \mathrm{Li}(\mathrm{I})$ ratios, and the processing is straightforward by a precipitation process, although the process has some drawbacks. ${ }^{6,8,10}$ Most brine in China and some brine in North America have relatively high $\mathrm{Mg}(\mathrm{II}) / \mathrm{Li}(\mathrm{I})$ ratios, hence the processing is more challenging. ${ }^{7,10-12}$ In recent years, progress has been made in several separation techniques for the recovery of $\mathrm{Li}(\mathrm{I})$ from $\mathrm{Mg}$ (II)-rich brine, including solvent extraction (SX), ${ }^{13-16}$ membrane separation, ${ }^{17-19}$ adsorption, ${ }^{20,21}$ and electrochemical methods. ${ }^{22}$ Among these separation techniques, the synergistic SX system consisting of tri- $n$-butyl phosphate (TBP) and $\mathrm{FeCl}_{3}$ is particularly suitable for $\mathrm{Li}(\mathrm{I})$ recovery from brine with high $\mathrm{Mg}(\mathrm{II}) / \mathrm{Li}$ (I) ratios because of the high $\mathrm{Li}(\mathrm{I}) / \mathrm{Mg}$ (II) selectivity and the low price of TBP. ${ }^{13,23-27}$ Recently, an improved process based on this SX system has solved the problem of difficult stripping, making upscaling more promising. ${ }^{28,29}$

The $\mathrm{TBP} / \mathrm{FeCl}_{3}$ synergistic SX system selectively extracts $\mathrm{Li}(\mathrm{I})$ from $\mathrm{Mg}(\mathrm{II})$-rich brine via the following mechanism ${ }^{30,31}$

$$
\mathrm{Fe}^{3+}+\mathrm{Li}^{+}+4 \mathrm{Cl}^{-}+x \overline{\mathrm{TBP}} \rightleftharpoons \overline{\left[\mathrm{Li}(\mathrm{TBP})_{x}\right]\left[\mathrm{FeCl}_{4}\right]}
$$

where $x=1$ or 2 , the overbar indicates that the compound resides in the organic phase. In this extraction reaction, the solvating extractant TBP forms a cationic complex with $\mathrm{Li}^{+}$, which is neutralized by the chlorometallate anion $\left[\mathrm{FeCl}_{4}\right]^{-}$.

Based on the above extraction mechanism, other stable anions should be able to play the same role as $\left[\mathrm{FeCl}_{4}\right]^{-}$to facilitate $\mathrm{Li}(\mathrm{I})$ extraction with TBP. This speculation has been proven by the efficient extraction of $\mathrm{Li}(\mathrm{I})$ by ionic liquids containing various anions, including $\left.\left[\mathrm{NTf}_{2}\right]^{-}, \mathrm{PF}_{6}\right]^{-, 32}\left[\mathrm{~B}(\mathrm{Ph})_{4}\right]^{-, 33}$ and

Received: March 14, 2021

Revised: $\quad$ May 5, 2021

Accepted: May 11, 2021

Published: June 3, 2021 
$\left[\mathrm{PW}_{12} \mathrm{O}_{40}\right]^{3-34}$ with TBP. However, many metal chlorides, including $\mathrm{CoCl}_{2}, \mathrm{NiCl}_{2}, \mathrm{MnCl}_{2}, \mathrm{CrCl}_{3}, \mathrm{CuCl}_{2}$, and $\mathrm{ZnCl}_{2}$, are much less efficient than $\mathrm{FeCl}_{3}$ in terms of $\mathrm{Li}(\mathrm{I})$ extraction with TBP, ${ }^{35,36}$ although some of them can also form stable chlorometallate anions similar to $\left[\mathrm{FeCl}_{4}\right]^{-}$. This study aims to understand the mechanism of $\mathrm{FeCl}_{3}$ facilitating higher $\mathrm{Li}(\mathrm{I})$ extraction efficiency than other chloride salts. Toward this end, we investigate the performance of five metal chlorides $\left(\mathrm{CuCl}_{2}\right.$, $\mathrm{AlCl}_{3}, \mathrm{FeCl}_{3}, \mathrm{InCl}_{3}$, and $\mathrm{SnCl}_{4}$ ) for selective extraction of $\mathrm{Li}(\mathrm{I})$ from $\mathrm{Mg}(\mathrm{II})$-rich brine with TBP, characterize the speciation in the organic phase of each extraction system, and demonstrate the unique property of $\mathrm{FeCl}_{3}$ that enables the most efficient extraction of $\mathrm{Li}(\mathrm{I})$.

\section{MATERIALS AND METHODS}

2.1. Chemicals. $\mathrm{HCl}(37 \%)$ was supplied by Fisher Scientific (Merelbeke, Belgium). $\mathrm{HNO}_{3}$ (65 wt \%) and Aliquat 336 ( $\sim 90 \%)$ were purchased from Sigma-Aldrich (Diegem, Belgium). $\mathrm{LiCl}^{(>99.5 \%)}$ was obtained from Carl Roth (Karlsruhe, Germany). $\mathrm{MgCl}_{2}$ (99\%), $\mathrm{AlCl}_{3}$ (anhydrous, 99\%), $\mathrm{FeCl}_{3}$ (>98\%), $\mathrm{CuCl}_{2}$ (>99\%), $\mathrm{InCl}_{3}$ (99.995\%), $\mathrm{SnCl}_{4}$ (99.99\%), and $p$-cymene (>99\%) were purchased from Acros Organics (Geel, Belgium). $\mathrm{Li}, \mathrm{Mg}, \mathrm{Al}, \mathrm{Fe}, \mathrm{Cu}, \mathrm{In}$, and $\mathrm{Sn}$ standard solutions $\left(1000 \pm 10 \mathrm{mg} \cdot \mathrm{L}^{-1}\right)$ and TBP $(>99 \%)$ were purchased from Chem-Lab (Zedelgem, Belgium). Ultrapure water was used to prepare aqueous solutions.

2.2. SX Experiments. Each extraction experiment was carried out in a $15 \mathrm{~mL}$ centrifuge tube with $5.0 \mathrm{~mL}$ of the aqueous solution and $5.0 \mathrm{~mL}$ of the organic solution containing either Aliquat 336 or TBP. Aliquat 336 was diluted in $p$-cymene; TBP was either diluted in $p$-cymene or used without dilution. $p$ Cymene is a sustainable substitute for toluene for diluting extractants since it can be derived from biomass. ${ }^{37}$ p-Cymene can be regarded as a model of the commercial diluent SOLVESSO 150 Fluid (a mixture of $\mathrm{C}_{10-12}$ alkylbenzenes). Mixtures of the two phases were shaken for $30 \mathrm{~min}$ at $300 \mathrm{rpm}$ using a Thermo Scientific 2000 shaker to attain extraction equilibrium. Afterward, the samples were centrifuged for $3 \mathrm{~min}$ at $4000 \mathrm{rpm}$ in a Heraeus Megafuge 1.0 centrifuge to accelerate phase separation. Extraction experiments using TBP were conducted in triplicate to ensure reliable stoichiometric ratio calculations. The loaded $\mathrm{Li}(\mathrm{I})$ and $\mathrm{Mg}$ (II) in the TBP phase were stripped using $6.0 \mathrm{~mol} \cdot \mathrm{L}^{-1} \mathrm{HCl}$. The aqueous phases at equilibrium and the resultant aqueous solutions after stripping were analyzed for metal concentrations by inductively coupled plasma-optical emission spectroscopy (ICP-OES) after appropriate dilutions using $2 \mathrm{wt} \% \mathrm{HNO}_{3}$. Metal concentrations in the organic phase [except for $\mathrm{Li}(\mathrm{I})$ and $\mathrm{Mg}(\mathrm{II})$ ] were calculated according to the mass balance due to the difficulty of stripping. All experiments were conducted at room temperature $\left(21 \pm 1{ }^{\circ} \mathrm{C}\right)$.

The percentage extraction $\% E$ is defined as

$$
\% E=\frac{c_{\text {org }} \cdot V_{\text {org }}}{c_{\text {org }} \cdot V_{\text {org }}+c_{\mathrm{aq}} \cdot V_{\mathrm{aq}}} \times 100 \%
$$

where $c_{\text {org }}$ and $c_{\text {aq, }}, V_{\text {org }}$ and $V_{\text {aq }}$ are concentrations and volumes of the organic and the aqueous phase at extraction equilibrium, respectively.

2.3. Analytical Instrumentation. $\mathrm{Li}(\mathrm{I}), \mathrm{Mg}(\mathrm{II}), \mathrm{Al}(\mathrm{III})$, $\mathrm{Fe}(\mathrm{III}), \mathrm{Cu}(\mathrm{II}), \mathrm{In}(\mathrm{III})$, and $\mathrm{Sn}(\mathrm{IV})$ concentrations were analyzed by a PerkinElmer Optima 8300 ICP-OES system equipped with a Scott Cross-Flow nebulizer. UV-vis absorption spectra were recorded by a Cary 6000i UV-vis-near-infrared spectrophotometer using a pair of quartz cuvettes $(10.0 \mathrm{~mm}$ path length). Raman spectra were measured on a Bruker VERTEX 70 spectrometer with a RAM II FT-Raman module laser $(\lambda=1064 \mathrm{~nm})$ at a power of $500 \mathrm{~mW}$. The electrospray ionization mass spectrometry (ESI-MS) spectra were recorded on a MicrOTOF-QII (Bruker) mass spectrometer. The samples for ESI-MS measurement were prepared in acetonitrile. Mass spectra were acquired in both positive and negative ion detection modes with the mass range from $\mathrm{m} / z=50$ to $\mathrm{m} / z=$ 1500.

\section{RESULTS AND DISCUSSIONS}

3.1. Formation of Chlorometallate Anions. Besides $\mathrm{FeCl}_{3}$, four additional metal chlorides $\left(\mathrm{AlCl}_{3}, \mathrm{CuCl}_{2}, \mathrm{InCl}_{3}\right.$, and $\mathrm{SnCl}_{4}$ ) were selected to extract $\mathrm{Li}(\mathrm{I})$ with $\mathrm{TBP}$ from $\mathrm{Mg}(\mathrm{II})$-rich solutions. These chlorides cover divalent, trivalent, and tetravalent metal salts. Based on the mechanism of $\mathrm{Li}(\mathrm{I})$ extraction by the synergistic SX system as shown in eq 1 , to be able to extract $\mathrm{Li}(\mathrm{I})$ the metal chloride should be able to form a chlorometallate anion to neutralize the cationic $\mathrm{Li}(\mathrm{I})$ complex $\left[\mathrm{Li}(\mathrm{TBP})_{x}\right]^{+}$. To evaluate the capability of the metal chlorides for the formation of the corresponding chlorometallate anions, we extracted these metal chlorides using Aliquat 336 (A336, a mixture of methyl-trialkyl ammonium chlorides with the alkyl chains being $\mathrm{C}_{8}-\mathrm{C}_{10}$ ), which is known to extract metal chlorides via the formation of chlorometallate anions. ${ }^{38-40}$

A mixture of the five metal chlorides was extracted by Aliquat 336 with varying $\mathrm{MgCl}_{2}$ concentrations as the chloride source (Figure 1). The extraction of $\mathrm{Al}(\mathrm{III})$ is very low, the extraction of

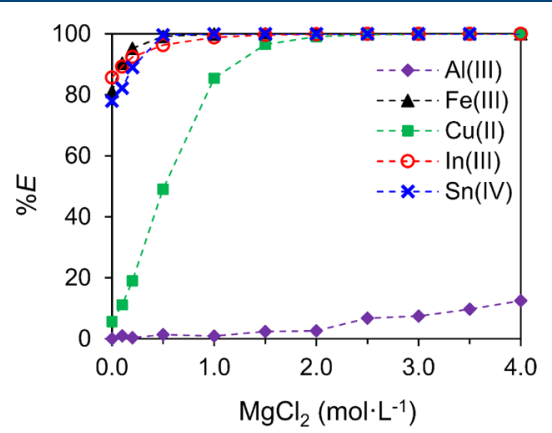

Figure 1. Extraction profiles of metal chlorides from their aqueous mixtures by Aliquat 336. The aqueous phase was $0.05 \mathrm{~mol} \cdot \mathrm{L}^{-1}$ of each metal chloride in a mixture; the organic phase was $50 \mathrm{vol} \%$ Aliquat 336 in $p$-cymene.

$\mathrm{Cu}$ (II) is moderate, while the extraction of $\mathrm{Fe}(\mathrm{III}), \mathrm{In}$ (III), and $\mathrm{Sn}(\mathrm{IV})$ is very strong. The sequence of extraction is $\mathrm{Al}(\mathrm{III}) \ll$ $\mathrm{Cu}(\mathrm{II})<\mathrm{In}(\mathrm{III}) \approx \mathrm{Fe}(\mathrm{III}) \approx \mathrm{Sn}(\mathrm{IV})$.

To confirm that all metal chlorides were extracted as anionic chlorometallate complexes, the Aliquat 336 phase (without diluent) loaded from each metal chloride alone [except for $\mathrm{AlCl}_{3}$ because of the low extraction of $\mathrm{Al}(\mathrm{III})]$ was characterized by either Raman or UV-vis absorption spectra (Figure 2). The Raman spectrum of the $\mathrm{Fe}$ (III)-A336 phase shows three bands at 333,134 , and $109 \mathrm{~cm}^{-1}$, respectively, which match very well with the Raman bands of $\left[\mathrm{FeCl}_{4}\right]^{-}$at 334,132 , and 112 $\mathrm{cm}^{-1}$. ${ }^{41,42}$ The bands at 321,113 , and $94 \mathrm{~cm}^{-1}$ in the Raman spectrum of the $\mathrm{In}$ (III)-A336 phase are characteristic for $\left[\mathrm{InCl}_{4}\right]^{-}$, as reported at $321,112,89 \mathrm{~cm}^{-1.43,44}$ The band at 291 $\mathrm{cm}^{-1}$ is attributed to $\left[\mathrm{InCl}_{5}\right]^{2-}$, as reported at $293 \mathrm{~cm}^{-1}$. Although $\mathrm{InCl}_{3}$ is extracted by Aliquat 336 mainly as $\left[\mathrm{InCl}_{4}\right]^{-}$, a 

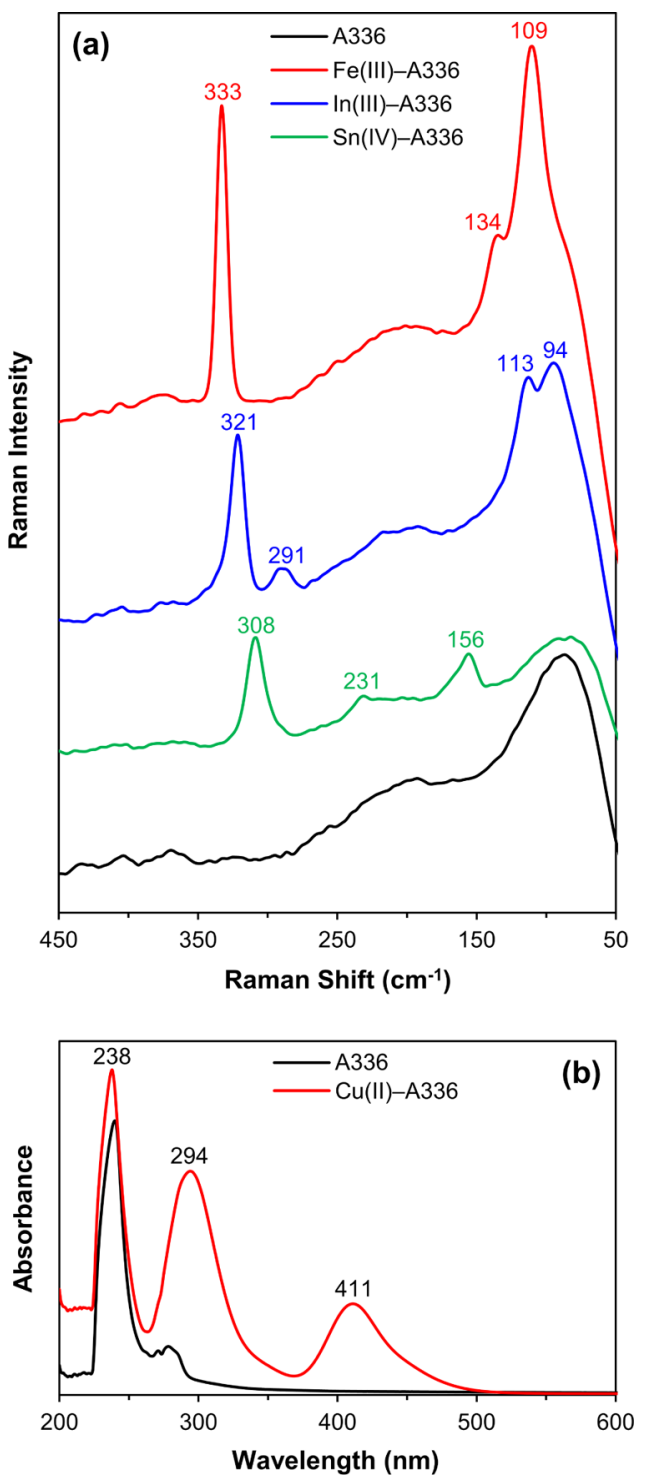

Figure 2. (a) Raman spectra and (b) UV-vis absorption spectra of the loaded A336 phases (without diluent).

small amount of $\left[\mathrm{InCl}_{5}\right]^{2-}$ can form, depending on the A336-to$\mathrm{InCl}_{3}$ ratio. $^{45,46}$ The bands at 308,231 , and $156 \mathrm{~cm}^{-1}$ in the Raman spectrum of the $\mathrm{Sn}(\mathrm{IV})-\mathrm{A} 336$ phase can be attributed to $\left[\mathrm{SnCl}_{6}\right]^{2-}$, as reported at 307,239 , and $160 \mathrm{~cm}^{-1}$. Concerning the $\mathrm{Cu}(\mathrm{II})-\mathrm{A} 336$ phase, UV-vis absorption spectra were recorded instead of Raman spectra because Raman spectra of the $\mathrm{Cu}(\mathrm{II})$ complexes were not observable using the equipped laser source $(\lambda=1064 \mathrm{~nm})$. Two maxima of the UV-vis absorption spectra at 294 and $411 \mathrm{~nm}$, respectively, are comparable to the absorption maxima of $\left[\mathrm{CuCl}_{4}\right]^{2-}$ in DMF at 296 and $411 \mathrm{~nm}$, respectively. ${ }^{48}$ Therefore, these chlorides $\left(\mathrm{CuCl}_{2}, \mathrm{FeCl}_{3}, \mathrm{InCl}_{3}\right.$, and $\left.\mathrm{SnCl}_{4}\right)$ were indeed extracted as chlorometallate anions. The tendency of the metal chlorides to form chlorometallate anions can be assumed to follow the same sequence as their extractability by Aliquat $336: \mathrm{Al}$ (III) $\ll \mathrm{Cu}$ (II) $<\mathrm{In}(\mathrm{III}) \approx \mathrm{Fe}(\mathrm{III}) \approx \mathrm{Sn}(\mathrm{IV})$. Considering the $\mathrm{Li}(\mathrm{I})$ extraction mechanism, we expect that the $\mathrm{Li}(\mathrm{I})$ extraction efficiency using these metal chlorides and TBP follows the same sequence.

3.2. Performance of Metal Chlorides in Li(I) Extraction. The five metal chlorides were used to extract $\mathrm{Li}(\mathrm{I})$ from $\mathrm{Mg}(\mathrm{II})$ rich solutions with TBP (Figure 3). As expected, the extraction of $\mathrm{Li}(\mathrm{I})$ by the $\mathrm{TBP} / \mathrm{AlCl}_{3}$ system was negligible, which can easily be explained by the incapability of $\mathrm{Al}$ (III) to form $\left[\mathrm{AlCl}_{4}\right]^{-}$in the system. Besides, the extraction of $\mathrm{Al}(\mathrm{III})$ was also negligible, meaning that $\mathrm{Al}$ (III) cannot be extracted by TBP as a solvation complex either. The extraction efficiency of $\mathrm{Li}(\mathrm{I})$ by the $\mathrm{TBP} / \mathrm{CuCl}_{2}$ system was also low, which might be explained by the relatively poor extraction of $\mathrm{Cu}(\mathrm{II})$, owing to the moderate capability of $\mathrm{Cu}(\mathrm{II})$ to form $\left[\mathrm{CuCl}_{4}\right]^{2-}$. $\mathrm{Fe}$ (III) was quantitatively extracted by the $\mathrm{TBP} / \mathrm{FeCl}_{3}$ system, and the extraction of $\mathrm{Li}(\mathrm{I})$ was $65-83 \%$, which is consistent with previous studies. ${ }^{13,28}$ The extraction of $\operatorname{In}($ III) was quantitative at low $\mathrm{InCl}_{3}$ concentrations but slightly decreased to $99 \%$ as the concentration of $\mathrm{InCl}_{3}$ increased. However, the extraction of $\mathrm{Li}(\mathrm{I})$ was $45-71 \%$, which is lower than that of the $\mathrm{TBP} / \mathrm{FeCl}_{3}$ system. Most surprisingly, the extraction of $\mathrm{Sn}(\mathrm{IV})$ was complete in the whole concentration range, but the extraction of $\mathrm{Li}(\mathrm{I})$ was less than $25 \%$. The lower $\mathrm{Li}(\mathrm{I})$ extraction by the $\mathrm{TBP} / \mathrm{InCl}_{3}$ system and the $\mathrm{TBP} / \mathrm{SnCl}_{4}$ system than the $\mathrm{TBP} /$ $\mathrm{FeCl}_{3}$ system contradicts the sequence of the chlorometallate anion formation; hence, further studies are required.

3.3. Evaluation of Stoichiometric Ratios. $\mathrm{Li}(\mathrm{I})$ is extracted as an ion-pair complex $\left[\mathrm{Li}(\mathrm{TBP})_{x}\right]\left[\mathrm{FeCl}_{4}\right]$ as shown in eq 1 in which the $\mathrm{Li}(\mathrm{I}) / \mathrm{Fe}(\mathrm{III})$ ratio is $1: 1$. Using this ratio, the amount of $\mathrm{Fe}$ (III) involved in the extraction of $\mathrm{Li}(\mathrm{I})$ can be calculated according to the amount of extracted $\mathrm{Li}(\mathrm{I})$ in Figure 3c. Similarly, $\mathrm{Mg}(\mathrm{II})$ can be assumed to be extracted as $\left[\mathrm{Mg}(\mathrm{TBP})_{x}\right]\left[\mathrm{FeCl}_{4}\right]_{2}$ in which the $\mathrm{Mg}(\mathrm{II}) / \mathrm{Fe}(\mathrm{III})$ ratio is $1: 2$. Using this ratio, the required $\mathrm{Fe}(\mathrm{III})$ for $\mathrm{Mg}$ (II) extraction can also be calculated according to the amount of extracted $\mathrm{Mg}$ (II) in Figure 3c. The calculated amount of $\mathrm{Fe}(\mathrm{III})$ for $\mathrm{Li}(\mathrm{I})$ and $\mathrm{Mg}$ (II) extraction was obtained and compared with the experimentally determined amount of $\mathrm{Fe}$ (III) (Figure 4a). It can be seen that the calculated amount of $\mathrm{Fe}(\mathrm{III})$ for $\mathrm{Li}(\mathrm{I})$ and $\mathrm{Mg}(\mathrm{II})$ extraction is slightly higher than the experimentally determined amount of $\mathrm{Fe}$ (III) in the organic phase. This might be explained by the fact that $\mathrm{Mg}$ (II) can bind a chloride anion to form $[\mathrm{MgCl}]^{+}, 4,50$ increasing the $\mathrm{Mg}$ (II)/Fe(III) ratio in the complex from $1: 2$ to $1: 1$, leading to a slight overestimation of the calculated amount of $\mathrm{Fe}$ (III). However, the high extraction of $\mathrm{Li}(\mathrm{I})$ and $\mathrm{Mg}(\mathrm{II})$ is an indication that (almost) all of the loaded $\mathrm{Fe}$ (III) was involved in the extraction of $\mathrm{Li}(\mathrm{I})$ and $\mathrm{Mg}(\mathrm{II})$.

Using the same principle applied for the $\mathrm{TBP} / \mathrm{FeCl}_{3}$ system, the theoretically required amount of $\mathrm{Cu}$ (II), In(III), and $\mathrm{Sn}$ (IV) for the extraction of the corresponding amounts of $\mathrm{Li}(\mathrm{I})$ and $\mathrm{Mg}(\mathrm{II})$ were also calculated for the TBP/CuCl $2, \mathrm{TBP} / \mathrm{InCl}_{3}$, and $\mathrm{TBP} / \mathrm{SnCl}_{4}$ systems (Figure $4 \mathrm{~b}-\mathrm{d}$ ). Interestingly, the calculated amounts of the metals in the organic phase are much lower than the corresponding experimentally determined amounts. The difference between the experimental amounts and the calculated amounts of metals are the metals extracted via a different mechanism than forming ion pairs with $\mathrm{Li}(\mathrm{I})$ or $\mathrm{Mg}$ (II). Considering that TBP is a solvating extractant, part of $\mathrm{Cu}(\mathrm{II}), \mathrm{In}(\mathrm{III})$, and $\mathrm{Sn}(\mathrm{IV})$ are likely extracted by TBP as neutral solvating complexes, although cationic complexes cannot be excluded.

In summary, the stoichiometric ratio calculations show that only $\mathrm{Fe}$ (III) (almost) completely forms ion pairs with $\mathrm{Li}(\mathrm{I})$ and $\mathrm{Mg}$ (II) to facilitate the efficient extraction of $\mathrm{Li}(\mathrm{I})$ and $\mathrm{Mg}(\mathrm{II})$; large portions of $\mathrm{Cu}(\mathrm{II}), \mathrm{In}(\mathrm{III})$, and $\mathrm{Sn}(\mathrm{IV})$ are loaded to the organic phase in other forms than forming ion-pairs with $\mathrm{Li}(\mathrm{I})$ and $\mathrm{Mg}(\mathrm{II})$.

3.4. Spectroscopic Study of the $\mathrm{Li}(\mathrm{I})-\mathrm{Mg}(\mathrm{II})-\mathrm{M}-\mathrm{TBP}$ Phase. The organic phases loaded with $\mathrm{Li}(\mathrm{I})$ and $\mathrm{Mg}(\mathrm{II})$ are 

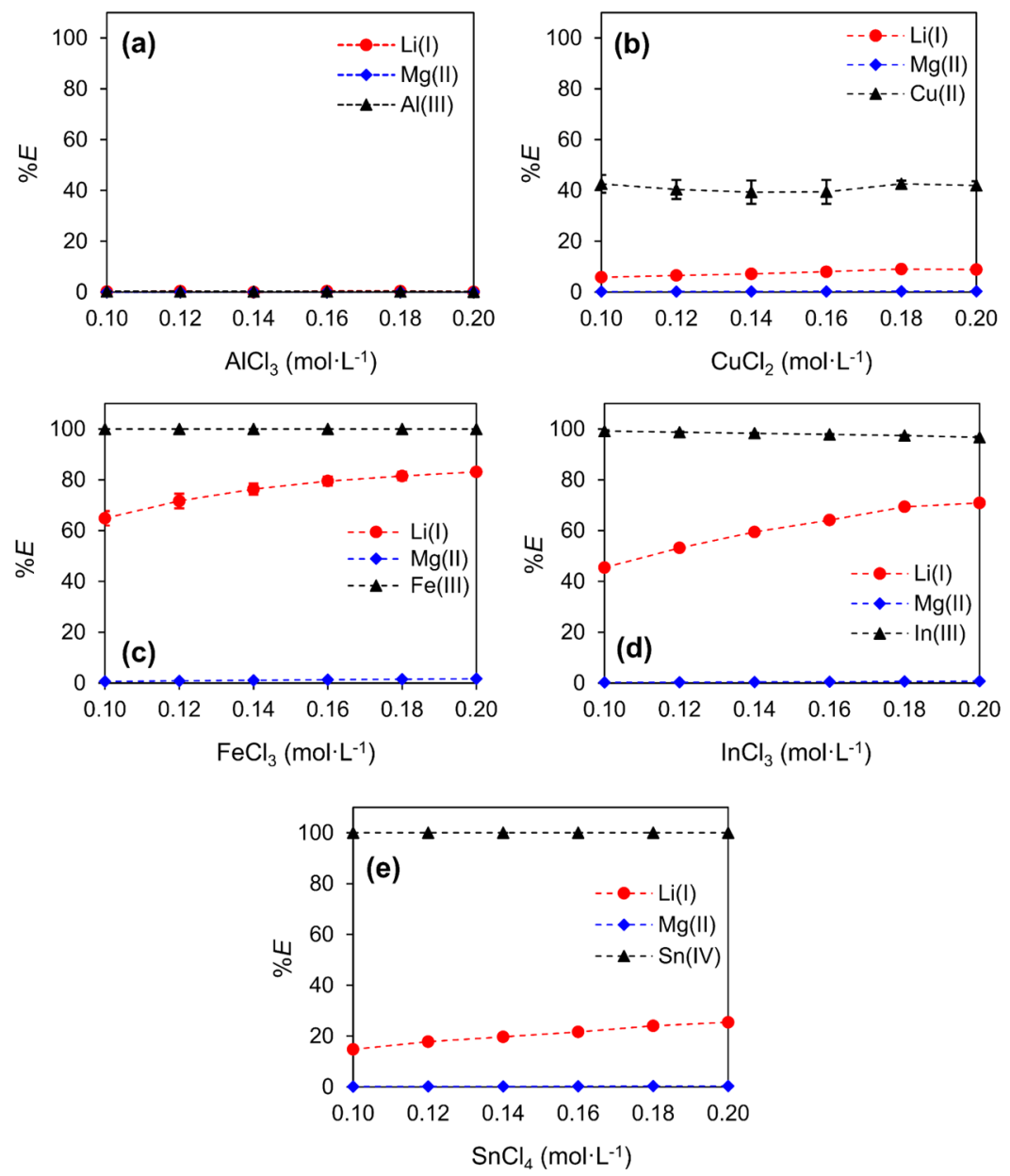

Figure 3. Extraction of $\mathrm{Li}(\mathrm{I})$ and $\mathrm{Mg}(\mathrm{II})$ to the TBP phase with the assistance of metal chloride salts: (a) $\mathrm{AlCl}_{3} ;$ (b) $\mathrm{CuCl}_{2}$; (c) $\mathrm{FeCl}_{3}$; (d) $\mathrm{InCl}_{3}$; and (e) $\mathrm{SnCl}_{4}$. The aqueous solution was $0.10 \mathrm{~mol} \cdot \mathrm{L}^{-1} \mathrm{LiCl}, 4.0 \mathrm{~mol} \cdot \mathrm{L}^{-1} \mathrm{MgCl}_{2}$, and $0.10-0.20 \mathrm{~mol} \cdot \mathrm{L}^{-1}$ of a chloride salt $\left(\mathrm{AlCl}_{3}, \mathrm{CuCl}_{2}, \mathrm{FeCl}_{3}, \mathrm{InCl}_{3}\right.$, or $\left.\mathrm{SnCl}_{4}\right)$; the organic phase was $60 \mathrm{vol} \% \mathrm{TBP}$ in $p$-cymene. Note that some error bars are too small to be seen.
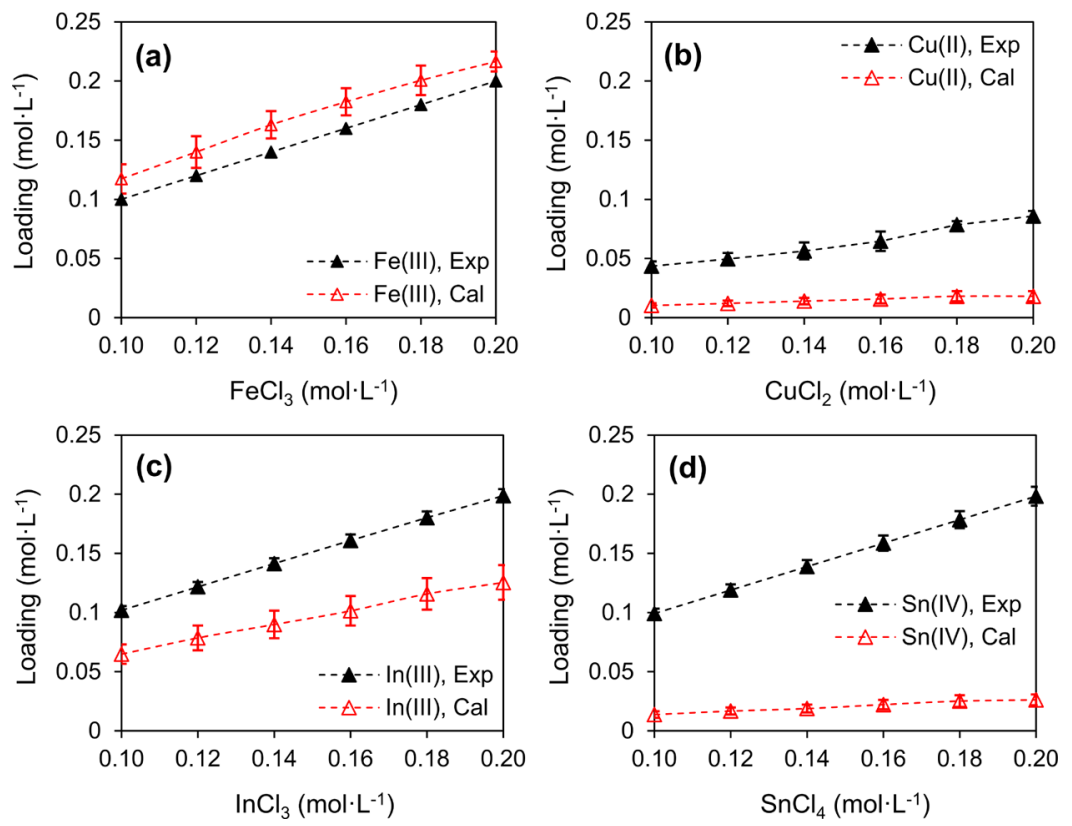

Figure 4. Loading of $\mathrm{Fe}(\mathrm{III}), \mathrm{Cu}(\mathrm{II}), \mathrm{In}(\mathrm{III})$, and $\mathrm{Sn}(\mathrm{IV})$ to the TBP phase by experimental measurements and by calculations according to Li(I) and $\mathrm{Mg}$ (II) loadings. The experimental data are the same as that in Figure 3. 
defined as $\mathrm{Li}(\mathrm{I})-\mathrm{Mg}(\mathrm{II})-\mathrm{M}-\mathrm{TBP}$, where $\mathrm{M}$ represents $\mathrm{Fe}(\mathrm{III}), \mathrm{Cu}(\mathrm{II}), \mathrm{In}(\mathrm{III})$, and $\mathrm{Sn}(\mathrm{IV})$. The Raman spectrum of the $\mathrm{Li}(\mathrm{I})-\mathrm{Mg}(\mathrm{II})-\mathrm{Fe}(\mathrm{III})-\mathrm{TBP}$ phase was recorded (Figure 5a). No extra bands are observable besides the three bands at
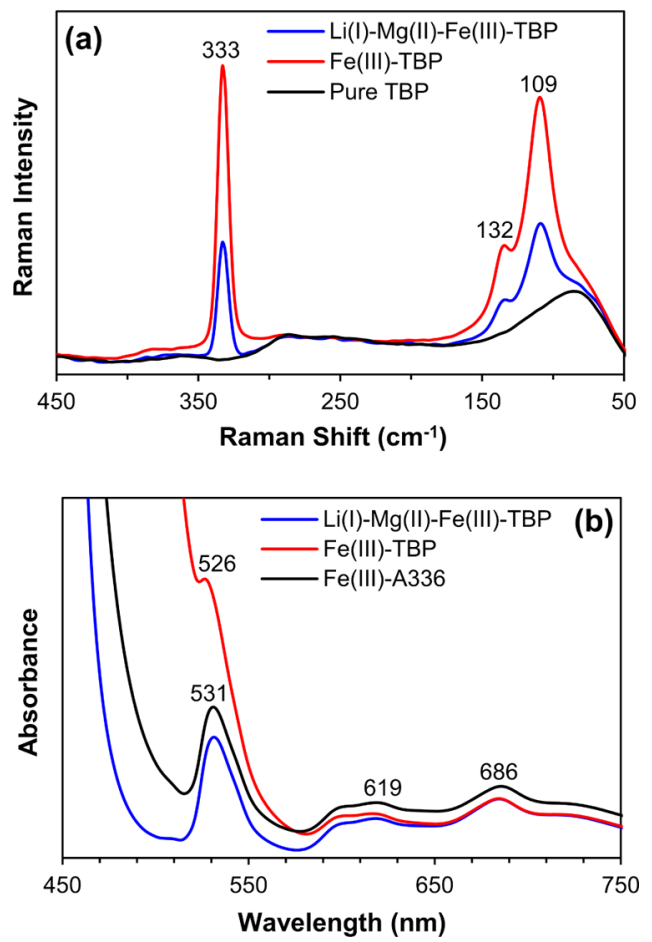

Figure 5. (a) Raman spectra and (b) UV-vis absorption spectra of the $\mathrm{Li}(\mathrm{I})-\mathrm{Mg}(\mathrm{II})-\mathrm{Fe}(\mathrm{III})-\mathrm{TBP}$ phase and the $\mathrm{Fe}(\mathrm{III})-\mathrm{TBP}$ phase.

333,132 , and $109 \mathrm{~cm}^{-1}$, which are the same as those for the $\mathrm{Fe}$ (III)-A336 phase (Figure 2a) and correspond to $\left[\mathrm{FeCl}_{4}\right]^{-41,42} \mathrm{UV}$-vis absorption spectra of the $\mathrm{Fe}(\mathrm{III})-\mathrm{A} 336$ phase shows three peaks at around 531, 619, and $686 \mathrm{~nm}$ (Figure $5 b)$, which are characteristic peaks of $\left[\mathrm{FeCl}_{4}\right]^{-31,51}$ The UV-vis absorption spectrum of the $\mathrm{Li}(\mathrm{I})-\mathrm{Mg}$ (II) $-\mathrm{Fe}(\mathrm{III})-\mathrm{TBP}$ phase also shows the same maxima as that of the $\mathrm{Fe}(\mathrm{III})-\mathrm{A} 336$ phase with very close molar absorptivities at 531, 619, and $686 \mathrm{~nm}$, respectively (Figure $5 \mathrm{~b}$ ). It is known that $\mathrm{A} 336$ extracts $\mathrm{Fe}(\mathrm{III})$ as $\left[\mathrm{FeCl}_{4}\right]^{-39,40}$ The excellent match of the Raman and UV-vis absorption spectra of the $\mathrm{Li}(\mathrm{I})-\mathrm{Mg}(\mathrm{II})-\mathrm{Fe}(\mathrm{III})-\mathrm{TBP}$ phase with that of the $\mathrm{Fe}(\mathrm{III})-\mathrm{A} 336$ phase indicates that $\left[\mathrm{FeCl}_{4}\right]^{-}$is also the only species in the $\mathrm{Li}(\mathrm{I})-\mathrm{Mg}$ (II) $-\mathrm{Fe}(\mathrm{III})-\mathrm{TBP}$ phase. This speculation agrees well with the stoichiometric ratio calculations (Figure $4 \mathrm{a}$ ) because only when $\left[\mathrm{FeCl}_{4}\right]^{-}$is the only species in the $\mathrm{Li}(\mathrm{I})-\mathrm{Mg}(\mathrm{II})-\mathrm{Fe}(\mathrm{III})-\mathrm{TBP}$ phase and all $\left[\mathrm{FeCl}_{4}\right]^{-}$are involved in the extraction of $\mathrm{Li}(\mathrm{I})$ and $\mathrm{Mg}(\mathrm{II})$ via ion-pair mechanism (shown in eq 1) could $\mathrm{Li}(\mathrm{I})$ and $\mathrm{Mg}$ (II) be extracted to the determined amounts.

The Raman spectrum of the $\mathrm{Li}(\mathrm{I})-\mathrm{Mg}(\mathrm{II})-\operatorname{In}(\mathrm{III})-\mathrm{TBP}$ phase shows three characteristic peaks of $\left[\mathrm{InCl}_{4}\right]^{-}$at 321,111 , and $92 \mathrm{~cm}^{-1}$ (Figure 6a). The $\left[\mathrm{InCl}_{4}\right]^{-}$anion facilitates the extraction of $\mathrm{Li}(\mathrm{I})$ or $\mathrm{Mg}(\mathrm{II})$ via the ion-pair mechanism. However, no extra bands are observed, although other species besides $\left[\mathrm{InCl}_{4}\right]^{-}$are speculated based on stoichiometric ratio calculations (Figure 4c). The absence of extra bands might be due to the low concentration or low Raman intensity of the species.

The bands of the Raman spectrum of the $\mathrm{Li}(\mathrm{I})-\mathrm{Mg}(\mathrm{II})-$ $\mathrm{Sn}(\mathrm{IV})-\mathrm{TBP}$ phase at 317,240 , and $155 \mathrm{~cm}^{-1}$ (Figure $6 \mathrm{~b}$ ) are
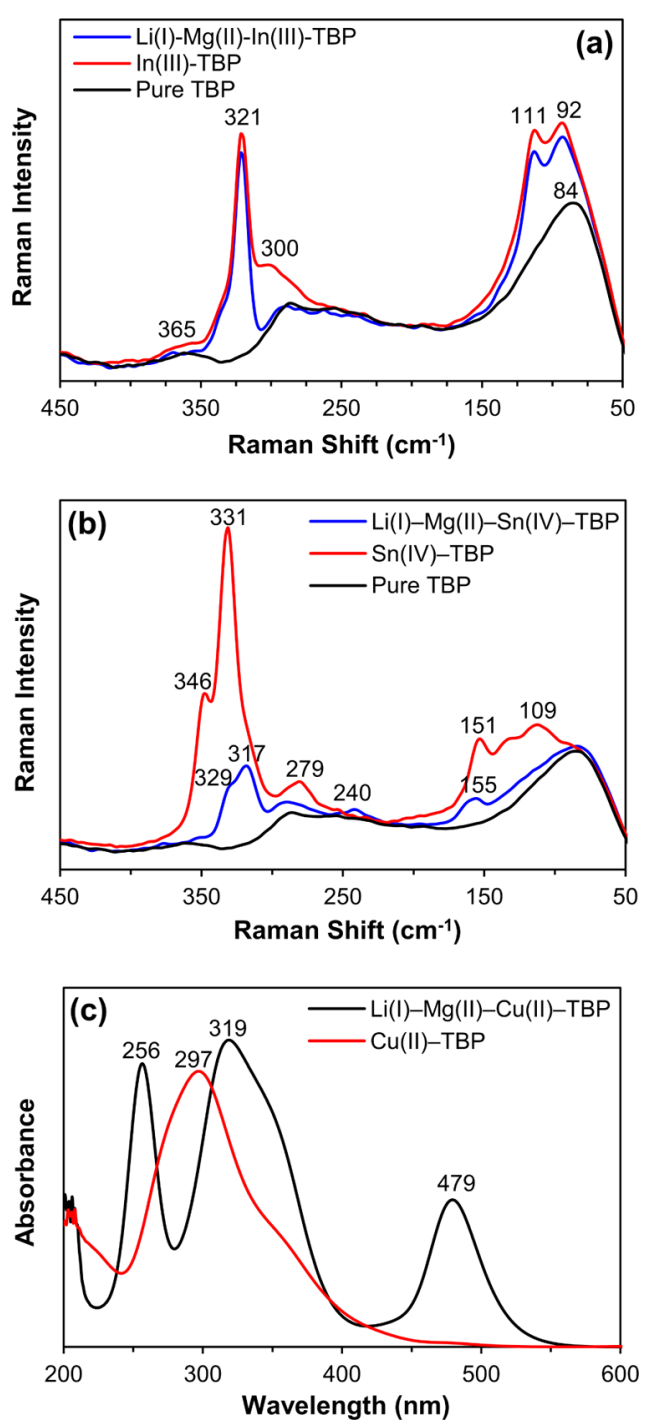

Figure 6. Raman spectra and UV-vis absorption spectra of the loaded TBP phases with and without $\mathrm{Li}(\mathrm{I})$ and $\mathrm{Mg}(\mathrm{II})$.

comparable to those of $\left[\mathrm{SnCl}_{6}\right]^{2-}$ at 308,231 , and $156 \mathrm{~cm}^{-1}$, as shown in Figure 2. The extra band at $329 \mathrm{~cm}^{-1}$ is due to the existence of other species, which is likely a neutral species, [i.e., $\left.\mathrm{SnCl}_{6}(\mathrm{TBP})_{x}\right]$ considering that TBP extracts many metal ions in neutral forms. The formation of other species besides $\left[\mathrm{SnCl}_{6}\right]^{2-}$ reduces the capability of the $\mathrm{SX}$ system to extract $\mathrm{Li}(\mathrm{I})$ and $\mathrm{Mg}(\mathrm{II})$.

The $\mathrm{Li}(\mathrm{I})-\mathrm{Mg}(\mathrm{II})-\mathrm{Cu}(\mathrm{II})-\mathrm{TBP}$ phase shows three absorption maxima in the UV-vis absorption spectrum (Figure $6 \mathrm{c}$ ). The maximum at $256 \mathrm{~nm}$ can be attributed to $[\mathrm{CuCl}]^{+}$; the two maxima at 319 and $479 \mathrm{~nm}$ are comparable to those observed in the absorption spectrum of $\left[\mathrm{CuCl}_{3}\right]^{-}$in acetic acid (at 300 and $450 \mathrm{~nm}$ ) and in DMF (at 300 and $440 \mathrm{~nm}$ ). ${ }^{48,52}$ On the other hand, the absorption maximum at $319 \mathrm{~nm}$ may also be due to the absorption of $\mathrm{CuCl}_{2}(\mathrm{TBP})_{x}$. Since both $\left[\mathrm{CuCl}(\mathrm{TBP})_{x}\right]^{+}$and $\left[\mathrm{CuCl}_{3}(\mathrm{TBP})_{x}\right]^{-}$exist in the solution, the existence of $\mathrm{CuCl}_{2}(\mathrm{TBP})_{x}$ is possible. Therefore, the $\mathrm{Li}(\mathrm{I})-\mathrm{Mg}(\mathrm{II})-\mathrm{Cu}-$ (II)-TBP phase is probably a mixture of $\left[\mathrm{CuCl}(\mathrm{TBP})_{x}\right]^{+}$, $\mathrm{CuCl}_{2}(\mathrm{TBP})_{x}$, and $\left[\mathrm{CuCl}_{3}(\mathrm{TBP})_{x}\right]^{-}$. The anionic $\left[\mathrm{CuCl}_{3}(\mathrm{TBP})_{x}\right]^{-}$can facilitate the extraction of $\mathrm{Li}(\mathrm{I})$ and $\mathrm{Mg}(\mathrm{II})$, but formation of $\left[\mathrm{CuCl}(\mathrm{TBP})_{x}\right]^{+}$and $\mathrm{CuCl}_{2}(\mathrm{TBP})_{x}$ would reduce the extraction efficiency. 
3.5. Loading of Metal Chlorides to Pure TBP. To evaluate the extractability of the metal chlorides by TBP as neutral solvating complexes, the five metal chlorides and $\mathrm{LiCl}$ and $\mathrm{MgCl}_{2}$ were directly and separately loaded to TBP without the addition of other salts or acids (Figure 7). The loadings of

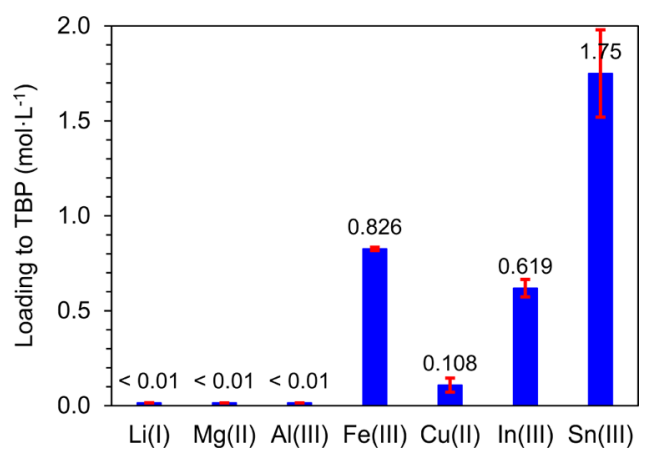

Figure 7. Loading of seven metal chlorides to pure TBP. The aqueous phase was $2.0 \mathrm{~mol} \cdot \mathrm{L}^{-1}$ of each metal chloride separately; the organic phase was pure TBP.

$\mathrm{Li}(\mathrm{I})$ and $\mathrm{Mg}(\mathrm{II})$ were both negligible, meaning that the extraction of $\mathrm{Li}(\mathrm{I})$ and $\mathrm{Mg}(\mathrm{II})$ by the synergistic SX systems is indeed via an ion-pair mechanism but not via a solvating mechanism. The loading of $\mathrm{Al}(\mathrm{III})$ is also negligible, consistent with the low loading in Figure 3a. The loading of $\mathrm{Cu}$ (II) is moderate, the loadings of $\mathrm{Fe}$ (III) and In(III) are comparable, and the loading of $\mathrm{Sn}(\mathrm{IV})$ is the highest. Considering that no salts or acids were added, the metals are expected to be loaded mainly as neutral solvating complexes. However, this hypothesis requires further elaboration.

The loaded Fe(III)-TBP phase has a deeper color than the loaded $\mathrm{Li}(\mathrm{I})-\mathrm{Mg}(\mathrm{II})-\mathrm{Fe}(\mathrm{III})-\mathrm{TBP}$ phase (Figure $8 \mathrm{a}, \mathrm{b}$ ) whose

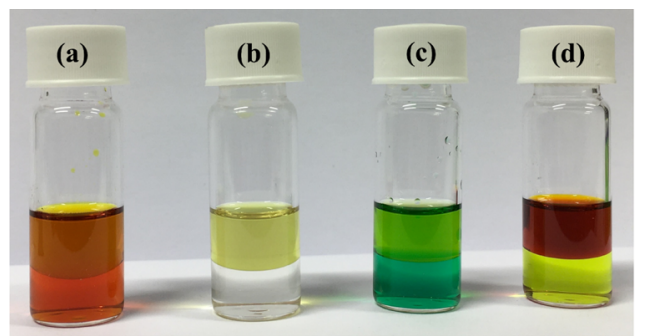

Figure 8. TBP phase loaded from (a) $2.0 \mathrm{~mol} \cdot \mathrm{L}^{-1} \mathrm{FeCl}_{3}$, (b) from a mixture of $0.10 \mathrm{~mol} \cdot \mathrm{L}^{-1} \mathrm{LiCl}, 0.20 \mathrm{~mol} \cdot \mathrm{L}^{-1} \mathrm{FeCl}_{3}$, and $4.0 \mathrm{~mol} \cdot \mathrm{L}^{-1}$ $\mathrm{MgCl}_{2}$, (c) from $2.0 \mathrm{~mol} \cdot \mathrm{L}^{-1} \mathrm{CuCl}_{2}$, and (d) from a mixture of 0.10 , $0.20 \mathrm{~mol} \cdot \mathrm{L}^{-1} \mathrm{CuCl}_{2}$, and $4.0 \mathrm{~mol} \cdot \mathrm{L}^{-1} \mathrm{MgCl}_{2}$.

color is known to be generated by $\left[\mathrm{FeCl}_{4}\right]^{-}$. The deeper color, on the one hand, might be due to a higher concentration of loaded $\mathrm{Fe}$ (III); on the other hand, it might be due to the formation of cationic complexes which neutralize $\left[\mathrm{FeCl}_{4}\right]^{-}$. Concerning the loaded $\mathrm{Cu}(\mathrm{II})-\mathrm{TBP}$ phase, the light-yellow color (organic phase of Figure 8c) is different from the brown color of the loaded $\mathrm{Li}(\mathrm{I})-\mathrm{Mg}(\mathrm{II})-\mathrm{Cu}(\mathrm{II})-\mathrm{TBP}$ phase (organic phase of Figure $8 \mathrm{~d}$ ). The gradual change of colors from blue (aqueous phase of Figure 8c), to light-yellow (organic phase of Figure 8c), to yellow (aqueous phase of Figure 8d), and to brown (organic phase of Figure $8 \mathrm{~d}$ ) is an indication of the increasing number of chloride ions bound to $\mathrm{Cu}$ (II).

3.6. Spectroscopic Study of the M-TBP Phase. Pure TBP loaded with a metal chloride is defined as M-TBP, where
M represents $\mathrm{Fe}(\mathrm{III}), \mathrm{Cu}(\mathrm{II}), \mathrm{In}(\mathrm{III})$, and $\mathrm{Sn}(\mathrm{IV})$. The Raman spectrum of the $\mathrm{Fe}$ (III)-TBP phase is the same as that of the $\mathrm{Li}(\mathrm{I})-\mathrm{Mg}(\mathrm{II})-\mathrm{Fe}(\mathrm{III})-\mathrm{TBP}$ phase, exhibiting three bands of $\left[\mathrm{FeCl}_{4}\right]^{-}$at 333,132 , and $109 \mathrm{~cm}^{-1}$ (Figure 5a). The UV-vis absorption spectrum of the $\mathrm{Fe}(\mathrm{III})-\mathrm{TBP}$ phase matches the spectrum of the $\mathrm{Li}(\mathrm{I})-\mathrm{Mg}(\mathrm{II})-\mathrm{Fe}(\mathrm{III})-\mathrm{TBP}$ phase at wavelengths longer than $650 \mathrm{~nm}$, but they differ at wavelengths shorter than $650 \mathrm{~nm}$ (Figure 5b). This observation indicates the formation of other species besides $\left[\mathrm{FeCl}_{4}\right]^{-}$, which awaits further determination.

Concerning the Raman spectrum of the In(III)-TBP phase, on top of the characteristic peaks of $\left[\mathrm{InCl}_{4}\right]^{-}$, an extra shoulder at $300 \mathrm{~cm}^{-1}$ is observed (Figure $6 \mathrm{a}$ ). This band might be attributed to the solvated neutral species $\operatorname{InCl}_{3}(\mathrm{TBP})_{x}$. Considering charge neutrality, $\left[\mathrm{InCl}_{2}\right]^{+}$may exist to neutralize $\left[\mathrm{InCl}_{4}\right]^{-}$because $\left[\mathrm{InCl}_{2}\right]^{+}$was previously found as a countercation for $\left[\mathrm{GaCl}_{4}\right]^{-53}$ A weak and broad band at around 365 $\mathrm{cm}^{-1}$ seems observable, matching the band of $\left[\mathrm{InCl}_{2}\right]^{+}$at about $367 \mathrm{~cm}^{-1}$. 53,54

The bands at 331 and $151 \mathrm{~cm}^{-1}$ in the spectrum of the $\mathrm{Sn}(\mathrm{IV})-\mathrm{TBP}$ phase might be due to $\left[\mathrm{SnCl}_{6}\right]^{2-}$ (Figure $6 \mathrm{~b}$ ). The counter-cation for $\left[\mathrm{SnCl}_{6}\right]^{2-}$ is probably $\left[\mathrm{SnCl}_{3}(\mathrm{TBP})_{x}\right]^{+}$since a similar compound, $\left[\mathrm{SnCl}_{3} \mathrm{~L}\right]_{2}\left[\mathrm{SnCl}_{6}\right](\mathrm{L}=1,4,7$-trimethyl$1,4,7$-triazacyclononane), was reported in the literature. ${ }^{55}$ Moreover, neutral species may also exist, considering the solvating property of TBP. Therefore, the three bands at 346, 279 , and $109 \mathrm{~cm}^{-1}$ might be due to $\left[\mathrm{SnCl}_{3}(\mathrm{TBP})_{x}\right]^{+}$and $\mathrm{SnCl}_{6}(\mathrm{TBP})_{x}$, although they cannot be completely assigned.

The absorption maximum of the $\mathrm{Cu}$ (II)-TBP phase in the $\mathrm{UV}$-vis spectrum at $297 \mathrm{~nm}$ (Figure 6c) is comparable to the one at $300 \mathrm{~nm}$ of the spectrum of the neutral $\mathrm{CuCl}_{2}$ in acetic acid. $^{52}$ This observation indicates that the main species in the loaded $\mathrm{Cu}(\mathrm{II})-\mathrm{TBP}$ phase is $\mathrm{CuCl}_{2}(\mathrm{TBP})_{x}$.

Combining the stoichiometric ratio calculations and spectroscopic studies, we can conclude that, besides chlorometallate anions, the M-TBP system and the $\mathrm{Li}(\mathrm{I})-\mathrm{Mg}(\mathrm{II})-\mathrm{M}-\mathrm{TBP}$ system $[\mathrm{M}=\mathrm{Cu}(\mathrm{II}), \mathrm{In}(\mathrm{III})$, and $\mathrm{Sn}(\mathrm{IV})]$ phases always have other species, which are very likely neutral solvated complexes. However, the $\mathrm{Li}(\mathrm{I})-\mathrm{Mg}(\mathrm{II})-\mathrm{Fe}(\mathrm{III})-\mathrm{TBP}$ phase contains only $\left[\mathrm{FeCl}_{4}\right]^{-}$, which is neutralized by $\mathrm{Li}(\mathrm{I})$ or $\mathrm{Mg}(\mathrm{II})$ ions. The $\mathrm{Fe}(\mathrm{III})-\mathrm{TBP}$ phase contains $\left[\mathrm{FeCl}_{4}\right]^{-}$and other unknown $\mathrm{Fe}$ (III)-complexes, which require further investigation.

3.7. Speciation of the Fe(III)-TBP Phase. The UV-vis absorption spectra of the $\mathrm{Mg}(\mathrm{II})-\mathrm{Fe}(\mathrm{III})-\mathrm{TBP}$ system [ $\mathrm{Li}(\mathrm{I})$ was omitted for simplicity] show the typical peaks of $\left[\mathrm{FeCl}_{4}\right]^{-}$ (Figure 9a). The spectrum of the Fe(III)-TBP system has the same shape as that of the $\mathrm{Mg}(\mathrm{II})-\mathrm{Fe}$ (III)-TBP system at wavelengths longer than $600 \mathrm{~nm}$, but the absorption is less intensive. At wavelengths shorter than $600 \mathrm{~nm}$, the spectrum of the $\mathrm{Fe}(\mathrm{III})-\mathrm{TBP}$ system is more intensive and shows a slight blue shift. On comparing the two spectra, it is speculated that the $\mathrm{Fe}(\mathrm{III})-\mathrm{TBP}$ system contains the $\left[\mathrm{FeCl}_{4}\right]^{-}$anion, and cations neutralizing the anion. These cations can be $\left[\mathrm{FeCl}_{x}(\mathrm{TBP})_{y}\right]^{3-x}$ $(x=0,1,2)$. The more intensive absorption at wavelengths shorter than $600 \mathrm{~nm}$ might be due to the absorption of the cations.

The absorption at wavelengths longer than $650 \mathrm{~nm}$ seems not affected by the existence of the speculative species, hence the absorption at $684 \mathrm{~nm}$ can be used to calculate the ratio of $\left[\mathrm{FeCl}_{4}\right]^{-}$in the $\mathrm{Fe}(\mathrm{III})-\mathrm{TBP}$ system. The molar absorptivity of $\left[\mathrm{FeCl}_{4}\right]^{-}$in the $\mathrm{Mg}(\mathrm{II})-\mathrm{Fe}(\mathrm{III})-\mathrm{TBP}$ system at $684 \mathrm{~nm}$ was determined to be about $0.636 \mathrm{~L} \cdot \mathrm{mol}^{-1} \cdot \mathrm{cm}^{-1}$ (Figure 9b). Assuming that $\left[\mathrm{FeCl}_{4}\right]^{-}$is the only $\mathrm{Fe}(\mathrm{III})$-containing species in 

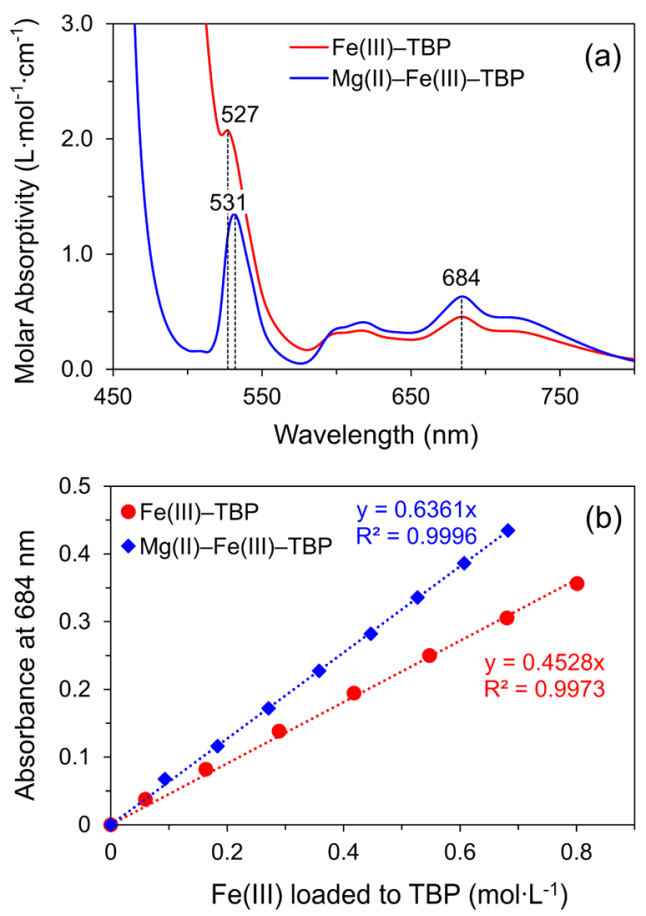

Figure 9. (a) UV-vis absorption spectra of the Fe(III)-TBP system and the $\mathrm{Mg}(\mathrm{II})-\mathrm{Fe}(\mathrm{III})-\mathrm{TBP}$ system and (b) absorption at $684 \mathrm{~nm}$ of the $\mathrm{Fe}(\mathrm{III})-\mathrm{TBP}$ system and the $\mathrm{Mg}$ (II) $-\mathrm{Fe}(\mathrm{III})-\mathrm{TBP}$ system loaded from varying concentrations of $\mathrm{FeCl}_{3}$ and mixtures of varying $\mathrm{FeCl}_{3}$ and $3.0 \mathrm{~mol} \cdot \mathrm{L}^{-1} \mathrm{MgCl}_{2}$, respectively.

the Fe(III)-TBP system, its molar absorptivity at $684 \mathrm{~nm}$ was determined to be about 0.453 (Figure $9 \mathrm{~b}$ ), which is about $71 \%$ of that in the $\mathrm{Mg}(\mathrm{II})-\mathrm{Fe}(\mathrm{III})-\mathrm{TBP}$ system. It can be inferred from this ratio that about $29 \%$ of the $\mathrm{Fe}$ (III) in the $\mathrm{Fe}$ (III)-TBP system are either cations or neutral complexes, and their average charge is +2.45 based on charge neutrality. Consider the extreme case that all cationic complexes are $\left[\mathrm{Fe}(\mathrm{TBP})_{x}\right]^{3+}$, then the sum of cations and anions account for $94.7 \%$ of total Fe(III), and the neutral species is $5.3 \%$. Because the cations are likely to have a mixture of different charges, the percentage of neutral species should be much smaller than 5.3\%.

3.8. ESI-MS of the Fe(III)-TBP Phase. To further validate the speciation in the $\mathrm{Fe}$ (III)-TBP system, ESI-MS spectra were recorded in both positive and negative modes. As expected, the anion $\left[\mathrm{FeCl}_{4}\right]^{-}(m / z=197.8)$ was observed (Figure 10).

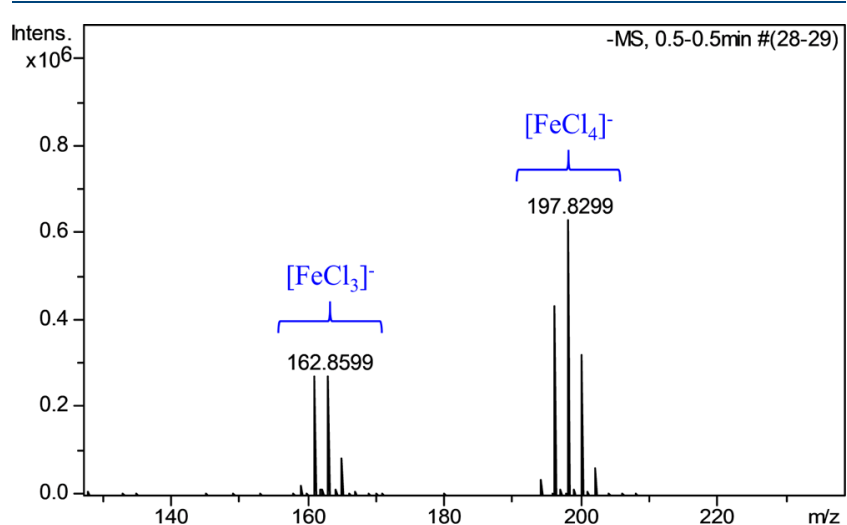

Figure 10. ESI-MS spectrum of the $\mathrm{Fe}(\mathrm{III})-\mathrm{TBP}$ system in the negative mode.
Besides, $\left[\mathrm{FeCl}_{3}\right]^{-}(m / z=162)$ was found, which is highly likely generated from $\left[\mathrm{FeCl}_{4}\right]^{-}$by in situ reduction of $\mathrm{Fe}$ (III) to $\mathrm{Fe}$ (II) in the ESI-MS system ${ }^{56,57}$ and loss of a chloride anion.

Multiple cations of $\mathrm{Fe}$ (III) were found by ESI-MS in the positive mode (Table 1, Figures $\mathrm{S} 1-\mathrm{S} 5$ ). Based on the

Table 1. Cations of the Fe(III)-TBP System Found in the Positive Mode in ESI-MS

\begin{tabular}{|c|c|c|c|}
\hline cations & $\begin{array}{l}m / z \\
\text { found }^{a}\end{array}$ & $\begin{array}{l}\text { relative } \\
\text { intensity }\end{array}$ & notes \\
\hline$\left[\mathrm{FeCl}_{2}\right]^{+}$ & 127.0 & 0.1 & \\
\hline$\left[\mathrm{FeCl}_{2}(\mathrm{TBP})\right]^{+}$ & 392.2 & 0.3 & \\
\hline$\left[\mathrm{FeCl}_{2}(\mathrm{TBP})_{2}\right]^{+}$ & 658.2 & 1.8 & \\
\hline$[\mathrm{FeCl}]^{2+}$ & 90.9 & 0.4 & $\begin{array}{l}\mathrm{Fe}(\mathrm{III}) \text { reduced to } \mathrm{Fe}(\mathrm{II}) \\
\quad z=1\end{array}$ \\
\hline$[\mathrm{FeCl}(\mathrm{TBP})]^{2+}$ & 357.1 & 0.8 & $\begin{array}{l}\mathrm{Fe}(\mathrm{III}) \text { reduced to } \mathrm{Fe}(\mathrm{II}) \\
\quad z=1\end{array}$ \\
\hline$\left[\mathrm{FeCl}(\mathrm{TBP})_{2}\right]^{2+}$ & $623.2^{b}$ & 31.1 & $\begin{array}{l}\mathrm{Fe}(\mathrm{III}) \text { reduced to } \mathrm{Fe}(\mathrm{II}) \\
\quad z=1\end{array}$ \\
\hline$\left[\mathrm{FeCl}(\mathrm{TBP})_{3}\right]^{2+}$ & 889.4 & 10.8 & $\begin{array}{l}\mathrm{Fe}(\mathrm{III}) \text { reduced to } \mathrm{Fe}(\mathrm{II}) \\
\quad z=1\end{array}$ \\
\hline $\mathrm{Fe}^{3+}$ & & 0.0 & \\
\hline$[\mathrm{Fe}(\mathrm{TBP})]^{3+}$ & & 0.0 & \\
\hline$\left[\mathrm{Fe}(\mathrm{TBP})_{2}\right]^{3+}$ & & 0.0 & \\
\hline$\left[\mathrm{Fe}(\mathrm{TBP})_{3}\right]^{3+}$ & $427.2^{c}$ & 25.1 & $\begin{array}{l}\mathrm{Fe}(\mathrm{III}) \text { reduced to } \mathrm{Fe}(\mathrm{II}) \\
\quad z=2\end{array}$ \\
\hline$\left[\mathrm{Fe}(\mathrm{TBP})_{4}\right]^{3+}$ & 560.3 & 29.6 & $\begin{array}{l}\mathrm{Fe}(\mathrm{III}) \text { reduced to } \mathrm{Fe}(\mathrm{II}) \\
z=2\end{array}$ \\
\hline
\end{tabular}

${ }^{a}$ Only the most intense peak is presented as a representative. ${ }^{b}$ This species may also be generated from $\left[\mathrm{FeCl}_{2}(\mathrm{TBP})_{2}\right]^{+}$through the loss of a chloride anion and reduction of $\mathrm{Fe}(\mathrm{III})$ to $\mathrm{Fe}(\mathrm{II}) .{ }^{c}$ This species may also be generated from $\left[\mathrm{FeCl}(\mathrm{TBP})_{3}\right]^{2+}$ through the loss of a chloride anion and reduction of $\mathrm{Fe}(\mathrm{III})$ to $\mathrm{Fe}(\mathrm{II})$.

intensities of the cations, $\left[\mathrm{FeCl}(\mathrm{TBP})_{2}\right]^{2+}(31.1 \%),[\mathrm{FeCl}-$ $\left.(\mathrm{TBP})_{3}\right]^{2+}(10.8 \%),\left[\mathrm{Fe}(\mathrm{TBP})_{3}\right]^{3+}(25.1 \%)$, and $\left[\mathrm{Fe}(\mathrm{TBP})_{4}\right]^{3+}$ $(29.6 \%)$ are the dominating species, the sum of which accounts for more than $96 \%$ of all cations. It should be noted that species in the solution of the SX systems can be different from the detected species in the ESI-MS spectra due to artifacts created by the measurement. The four dominating species were not directly detected but were speculated by taking into account the reduction of $\mathrm{Fe}$ (III) to $\mathrm{Fe}$ (II). Besides, alternative to the assignment of species in Table 1 , the detected $\left[\mathrm{FeCl}(\mathrm{TBP})_{2}\right]^{+}$ $[m / z=623.2, \mathrm{Fe}(\mathrm{II})]$ and $\left[\mathrm{Fe}(\mathrm{TBP})_{3}\right]^{2+}[\mathrm{m} / z=427.2, \mathrm{Fe}(\mathrm{II})]$ may also be generated from $\left[\mathrm{FeCl}_{2}(\mathrm{TBP})_{2}\right]^{+}$and $[\mathrm{FeCl}-$ $\left.(\mathrm{TBP})_{3}\right]^{2+}$, respectively, through the loss of a chloride anion and reduction of $\mathrm{Fe}$ (III) to $\mathrm{Fe}$ (II), as what happened to the change from $\left[\mathrm{FeCl}_{4}\right]^{-}$to $\left[\mathrm{FeCl}_{3}\right]^{-}$. This assumption is based on the fact that $\mathrm{Fe}$ (III) often exhibits a stable coordination number of 4 (neglecting the dimerization of TBP). Overall, it can be concluded that $\left[\mathrm{FeCl}(\mathrm{TBP})_{x}\right]^{2+}(x=2,3)$ and $\left[\mathrm{Fe}(\mathrm{TBP})_{\mathrm{y}}\right]^{3+}(y$ $=3,4)$ are the main cations, although a small portion of $\left[\mathrm{FeCl}_{2}(\mathrm{TBP})_{2}\right]^{+}$also exists. The average charge of the cations in Table 1 is +2.53 , very close to the calculated value of +2.47 based on the percentage of $\left[\mathrm{FeCl}_{4}\right]^{-}$determined by $\mathrm{UV}-$ vis absorption spectra (Figure 9). This comparison indicates that the species in the $\mathrm{Fe}(\mathrm{III})-\mathrm{TBP}$ phase are mainly $\left[\mathrm{FeCl}_{4}\right]^{-}$and a mixture of cations. Consequently, the amount of neutral species is negligible.

In the absence of counter-cations (e.g., $\mathrm{Li}^{+}, \mathrm{Mg}^{2+}$ ), the $\mathrm{Fe}(\mathrm{III})-\mathrm{TBP}$ system forms a mixture of $\left[\mathrm{FeCl}(\mathrm{TBP})_{x}\right]^{2+}(x=2$, $3)$ and $\left[\mathrm{Fe}(\mathrm{TBP})_{\mathrm{y}}\right]^{3+}(y=3,4)$ as the counter-cations of $\left[\mathrm{FeCl}_{4}\right]^{-}$. In the presence of counter-cations (e.g., $\mathrm{Li}^{+}, \mathrm{Mg}^{2+}$ ), 
$\left[\mathrm{FeCl}(\mathrm{TBP})_{x}\right]^{2+}(x=2,3)$ and $\left[\mathrm{Fe}(\mathrm{TBP})_{y}\right]^{3+}(y=3,4)$ would transform to $\left[\mathrm{FeCl}_{4}\right]^{-}$(Figure S6), hence facilitating efficient extraction of $\mathrm{Li}(\mathrm{I})$ via the ion-pair mechanism.

\section{CONCLUSIONS}

The mechanism of $\mathrm{FeCl}_{3}$ facilitating much higher $\mathrm{Li}(\mathrm{I})$ extraction efficiency in the form of $\left[\mathrm{Li}(\mathrm{TBP})_{x}\right]\left[\mathrm{FeCl}_{4}\right]$ than other metal chlorides with TBP has been investigated by comparing the performance of five metal chlorides $\left(\mathrm{CuCl}_{2}\right.$, $\mathrm{AlCl}_{3}, \mathrm{FeCl}_{3}, \mathrm{InCl}_{3}$, and $\mathrm{SnCl}_{4}$ ). Through stoichiometric ratio calculations for the extracted complexes and detailed spectroscopic studies, it has been found that the coordination capability of the chloride salts plays a critical role in the extraction of $\mathrm{Li}(\mathrm{I})$. The five investigated chloride salts can be categorized into three groups in terms of their coordination property and $\mathrm{Li}(\mathrm{I})$ extraction efficiency:

(1). $\mathrm{AlCl}_{3}$ cannot form chlorometallate anion (i.e., $\left[\mathrm{AlCl}_{4}\right]^{-}$) under the extraction conditions, hence the $\mathrm{TBP} / \mathrm{AlCl}_{3}$ system could not extract $\mathrm{Li}(\mathrm{I})$ at all.

(2). $\mathrm{CuCl}_{2}, \mathrm{InCl}_{3}$, and $\mathrm{SnCl}_{4}$ can form chlorometallate anions (i.e., $\left[\mathrm{CuCl}_{4}\right]^{2-},\left[\mathrm{InCl}_{4}\right]^{-}$, and $\left.\left[\mathrm{SnCl}_{6}\right]^{2-}\right)$, which in principle can facilitate the extraction of $\mathrm{Li}(\mathrm{I})$. However, these metal chlorides also form other species (most likely neutral solvation complexes) with TBP, inhibiting the formation of chlorometallate anions.

(3). $\mathrm{FeCl}_{3}$ does not form neutral solvation complexes and tends to form the maximum amount of $\left[\mathrm{FeCl}_{4}\right]^{-}$in the TBP phase.

Other metal chlorides might be categorized into the above three groups as well in terms of their capability to extract $\mathrm{Li}(\mathrm{I})$ with TBP. Concurrently being able to form $\left[\mathrm{FeCl}_{4}\right]^{-}$strongly and to avoid forming neutral solvation complexes with TBP is the unique property of $\mathrm{FeCl}_{3}$ that makes $\mathrm{FeCl}_{3}$ most efficient for $\mathrm{Li}(\mathrm{I})$ extraction with TBP.

\section{ASSOCIATED CONTENT}

\section{SI Supporting Information}

The Supporting Information is available free of charge at https://pubs.acs.org/doi/10.1021/acs.iecr.1c01003.

ESI-MS spectra of the $\mathrm{Fe}(\mathrm{III})-\mathrm{TBP}$ phase in positive mode $(\mathrm{m} / z=50-1000)$ and UV-vis absorption spectra of the $\mathrm{Mg}(\mathrm{II})-\mathrm{Fe}(\mathrm{III})-\mathrm{TBP}$ phase as a function of $\mathrm{MgCl}_{2}$ concentration (PDF)

\section{AUTHOR INFORMATION}

\section{Corresponding Author}

Zheng Li - Department of Chemistry, KU Leuven, B-3001

Heverlee, Belgium; (i) orcid.org/0000-0002-7882-5999;

Email: zheng.li@kuleuven.be

\section{Author \\ Koen Binnemans - Department of Chemistry, KU Leuven, B- 3001 Heverlee, Belgium; 이이. org/0000-0003-4768- 3606}

Complete contact information is available at:

https://pubs.acs.org/10.1021/acs.iecr.1c01003

\section{Notes}

The authors declare no competing financial interest.

\section{ACKNOWLEDGMENTS}

Z.L. was supported by the Senior FWO Postdoctoral Fellowship $(181203 / 12 Z I 920 N)$. K.B. acknowledges funding from the European Research Council (ERC) under the European Union's Horizon 2020 Research and Innovation Programme: Grant Agreement 694078-Solvometallurgy for critical metals (SOLCRIMET). Hui $\mathrm{Su}$ is acknowledged for assistance in obtaining the ESI-MS spectra.

\section{REFERENCES}

(1) U.S. Geological Survey, 2019. Mineral Commodity Summaries 2019; U.S. Geological Survey, 2019; p 200.

(2) Li, Z.; Binnemans, K. Selective removal of magnesium from lithium-rich brine for lithium purification by synergic solvent extraction using $\beta$-diketones and Cyanex 923. AIChE J. 2020, 66, No. el6246.

(3) Statista. Total global consumption of lithium from 2008 to 2016. https://www.statista.com/statistics / 451999 /global-totalconsumption-of-lithium/ (accessed on 10 December, 2020).

(4) Miedema, J. H.; Moll, H. C. Lithium availability in the EU27 for battery-driven vehicles: The impact of recycling and substitution on the confrontation between supply and demand until 2050. Resour. Pol. 2013, 38, 204-211.

(5) The World Bank Group. Minerals for Climate Action: The Mineral Intensity of the Clean Energy Transition, 2020. http:// pubdocs.worldbank.org/en/961711588875536384/Minerals-forClimate-Action-The-Mineral-Intensity-of-the-Clean-EnergyTransition.pdf (accessed on 10 December, 2020).

(6) Swain, B. Recovery and recycling of lithium: A review. Sep. Purif. Technol. 2017, 172, 388-403.

(7) Kesler, S. E.; Gruber, P. W.; Medina, P. A.; Keoleian, G. A.; Everson, M. P.; Wallington, T. J. Global lithium resources: Relative importance of pegmatite, brine and other deposits. Ore Geol. Rev. 2012, $48,55-69$.

(8) Meshram, P.; Pandey, B. D.; Mankhand, T. R. Extraction of lithium from primary and secondary sources by pre-treatment, leaching and separation: A comprehensive review. Hydrometallurgy 2014, 150, 192-208.

(9) Choubey, P. K.; Kim, M.-s.; Srivastava, R. R.; Lee, J.-c.; Lee, J.-Y. Advance review on the exploitation of the prominent energy-storage element: Lithium. Part I: From mineral and brine resources. Miner. Eng. 2016, 89, 119-137.

(10) Tran, T.; Luong, V. T. Lithium Production Processes. In Lithium Process Chemistry; Chagnes, A., Światowska, J., Eds.; Elsevier: Amsterdam, 2015; Chapter 3, pp 81-124.

(11) Li, Z.; Mercken, J.; Li, X.; Riaño, S.; Binnemans, K. Efficient and Sustainable Removal of Magnesium from Brines for Lithium/ Magnesium Separation Using Binary Extractants. ACS Sustainable Chem. Eng. 2019, 7, 19225-19234.

(12) Song, J. F.; Nghiem, L. D.; Li, X.-M.; He, T. Lithium extraction from Chinese salt-lake brines: opportunities, challenges, and future outlook. Environ. Sci.: Water Res. Technol. 2017, 3, 593-597.

(13) Zhou, Z.; Qin, W.; Liang, S.; Tan, Y.; Fei, W. Recovery of lithium using tributyl phosphate in methyl isobutyl ketone and $\mathrm{FeCl}$. Ind. Eng. Chem. Res. 2012, 51, 12926-12932.

(14) Zhou, Z.; Liu, H.; Fan, J.; Liu, X.; Hu, Y.; Hu, Y.; Wang, Y.; Ren, Z. Selective Extraction of Lithium Ion from Aqueous Solution with Sodium Phosphomolybdate As a Coextraction Agent. ACS Sustainable Chem. Eng. 2019, 7, 8885-8892.

(15) Shi, C.; Jing, Y.; Jia, Y. Solvent extraction of lithium ions by tri-nbutyl phosphate using a room temperature ionic liquid. J. Mol. Liq. 2016, 215, 640-646.

(16) Torrejos, R. E. C.; Nisola, G. M.; Song, H. S.; Limjuco, L. A.; Lawagon, C. P.; Parohinog, K. J.; Koo, S.; Han, J. W.; Chung, W.-J. Design of lithium selective crown ethers: Synthesis, extraction and theoretical binding studies. Chem. Eng. J. 2017, 326, 921-933.

(17) Zhang, C.; Mu, Y.; Zhao, S.; Zhang, W.; Wang, Y. Lithium extraction from synthetic brine with high $\mathrm{Mg}^{2+} / \mathrm{Li}^{+}$ratio using the polymer inclusion membrane. Desalination 2020, 496, 114710. 
(18) Li, X.; Mo, Y.; Qing, W.; Shao, S.; Tang, C. Y.; Li, J. Membranebased technologies for lithium recovery from water lithium resources: A review. J. Membr. Sci. 2019, 591, 117317.

(19) Gmar, S.; Chagnes, A. Recent advances on electrodialysis for the recovery of lithium from primary and secondary resources. Hydrometallurgy 2019, 189, 105124.

(20) Li, L.; Deshmane, V. G.; Paranthaman, M. P.; Bhave, R.; Moyer, B. A.; Harrison, S. Lithium recovery from aqueous resources and batteries: a brief review. Johnson Matthey Technol. Rev. 2018, 62, 161176.

(21) Xiao, J.-L.; Sun, S.-Y.; Song, X.; Li, P.; Yu, J.-G. Lithium ion recovery from brine using granulated polyacrylamide-MnO 2 ion-sieve. Chem. Eng. J. 2015, 279, 659-666.

(22) Battistel, A.; Palagonia, M. S.; Brogioli, D.; La Mantia, F.; Trócoli, R. Electrochemical Methods for Lithium Recovery: A Comprehensive and Critical Review. Adv. Mater. 2020, 32, 1905440.

(23) Nelli, J. R.; Arthur, T. E., Jr. Recovery of Lithium from Bitterns, U.S. Patent US 3,537,813 A, 1970.

(24) Shanghai Institute of Organic Chemistry. Preliminary study on the extraction of lithium from magnesium saturated solutions. J. Salt Lake Res. 1975, 1-22.

(25) Xiang, W.; Liang, S.; Zhou, Z.; Qin, W.; Fei, W. Lithium recovery from salt lake brine by counter-current extraction using tributyl phosphate $/ \mathrm{FeCl} 3$ in methyl isobutyl ketone. Hydrometallurgy 2017, $171,27-32$.

(26) Shi, D.; Cui, B.; Li, L.; Peng, X.; Zhang, L.; Zhang, Y. Lithium extraction from low-grade salt lake brine with ultrahigh $\mathrm{Mg} / \mathrm{Li}$ ratio using TBP - kerosene $-\mathrm{FeCl}_{3}$ system. Sep. Purif. Technol. 2019, 211, 303-309.

(27) Li, Z.; Binnemans, K. Opposite selectivities of tri-n-butyl phosphate (TBP) and Cyanex 923 in solvent extraction of lithium and magnesium. AIChE J. 2021, 67, No. e17219.

(28) Su, H.; Li, Z.; Zhang, J.; Liu, W.; Zhu, Z.; Wang, L.; Qi, T. Combining Selective Extraction and Easy Stripping of Lithium Using a Ternary Synergistic Solvent Extraction System through Regulation of Fe3+ Coordination. ACS Sustainable Chem. Eng. 2020, 8, 1971-1979.

(29) Su, H.; Li, Z.; Zhang, J.; Zhu, Z.; Wang, L.; Qi, T. Recovery of lithium from salt lake brine using a mixed ternary solvent extraction system consisting of TBP, $\mathrm{FeCl}_{3}$ and P507. Hydrometallurgy 2020, 197, 105487.

(30) Zhou, Z.; Qin, W.; Chu, Y.; Fei, W. Elucidation of the structures of tributyl phosphate/Li complexes in the presence of $\mathrm{FeCl} 3$ via UVvisible, Raman and IR spectroscopy and the method of continuous variation. Chem. Eng. Sci. 2013, 101, 577-585.

(31) Su, H.; Li, Z.; Zhu, Z.; Wang, L.; Qi, T. Extraction relationship of $\mathrm{Li}+$ and $\mathrm{H}+$ using tributyl phosphate in the presence of $\mathrm{Fe}(\mathrm{III})$. Sep. Sci. Technol. 2020, 55, 1677-1685.

(32) Shi, C.; Jia, Y.; Jing, Y. Lithium and magnesium separation from salt lake brine by ionic liquids containing tributyl phosphate. CIESC J. 2015, 66, 253-259.

(33) Kuz'min, V. I.; Gudkova, N. V. Extraction of Lithium Using TBP and the Noncoordinating Cation Exchanger Tetraphenylborate: Principles of Selectivity from Sodium and Higher-Valent Cations. Solvent Extr. Ion Exch. 2015, 33, 183-195.

(34) Wang, Y.; Liu, H.; Fan, J.; Liu, X.; Hu, Y.; Hu, Y.; Zhou, Z.; Ren, Z. Recovery of Lithium Ions from Salt Lake Brine with a High Magnesium/Lithium Ratio Using Heteropolyacid Ionic Liquid. ACS Sustainable Chem. Eng. 2019, 7, 3062-3072.

(35) Zhou, Z.; Qin, W.; Fei, W. Extraction equilibria of lithium with tributyl phosphate in three diluents. J. Chem. Eng. Data 2011, 56, 35183522.

(36) Li, H.-f.; Li, L.-j.; Li, W. Lithium Extraction from Aqueous Solution using Different Metal Chloride as Co-extraction Reagent. Chem. Phys. Lett. 2020, 754, 137675.

(37) Li, Z.; Smith, K. H.; Stevens, G. W. The use of environmentally sustainable bio-derived solvents in solvent extraction applications-a review. Chin. J. Chem. Eng. 2016, 24, 215-220.

(38) Sato, T.; Shimomura, T.; Murakami, S.; Maeda, T.; Nakamura, T. Liquid-liquid extraction of divalent manganese, cobalt, copper, zinc and cadmium from aqueous chloride solutions by tricaprylmethylammonium chloride. Hydrometallurgy 1984, 12, 245-254.

(39) Mishra, R. K.; Rout, P. C.; Sarangi, K.; Nathsarma, K. C. Solvent extraction of $\mathrm{Fe}(\mathrm{III})$ from the chloride leach liquor of low grade iron ore tailings using Aliquat 336. Hydrometallurgy 2011, 108, 93-99.

(40) Li, Z.; Zhang, Z.; Smolders, S.; Li, X.; Raiguel, S.; Nies, E.; De Vos, D. E.; Binnemans, K. Enhancing Metal Separations by LiquidLiquid Extraction Using Polar Solvents. Chem. Eur. J. 2019, 25, 91979201.

(41) Shamir, J.; Sobota, P. Raman spectrum of $\left[\mathrm{MgCl}(\mathrm{THF})_{5}\right]$ $\left[\mathrm{FeCl}_{4}\right]$ THF. J. Raman Spectrosc. 1991, 22, 535-536.

(42) Shamir, J.; van der Veken, B. J.; Herman, M. A.; Rafaeloff, R. Raman and IR spectra of tetrachloro phosphonium salts of some tetrachlorate $\left(\mathrm{MCI}_{4}^{-}\right)$anions. J. Raman Spectrosc. 1981, 11, 215-220.

(43) Cho, J.-S.; Cho, H.-G. $\mathrm{InCl}_{4}{ }^{-}$observed in the Raman Spectra of Deuterated Acetonitrile Containing $\mathrm{InCl}_{3}$. J. Korean Chem. Soc. 2007, 51, 287-290.

(44) Cho, J.-S.; Cho, H.-G. Variation in IR and Raman Spectra of $\mathrm{CD}_{3} \mathrm{CN}$ upon Solvation of $\mathrm{InCl}_{3}$ in $\mathrm{CD}_{3} \mathrm{CN}$ : Distinctive Blue Shifts, Coordination Number, Donor-Acceptor Interaction, and Solvated Species. Bull. Korean Chem. Soc. 2009, 30, 803-809.

(45) Yang, J.-Z.; Tian, P.; He, L.-L.; Xu, W.-G. Studies on room temperature ionic liquid InCl3-EMIC. Fluid Phase Equilib. 2003, 204, $295-302$.

(46) Deferm, C.; Onghena, B.; Vander Hoogerstraete, T.; Banerjee, D.; Luyten, J.; Oosterhof, H.; Fransaer, J.; Binnemans, K. Speciation of indium(iii) chloro complexes in the solvent extraction process from chloride aqueous solutions to ionic liquids. Dalton Trans. 2017, 46, 4412-4421.

(47) Ouasri, A.; Elyoubi, M. S. D.; Guedira, T.; Rhandour, A.; Mhiri, T.; Daoud, A. Synthesis, DTA IR and raman spectra of penthylenediammonium hexachlorostannate $\mathrm{NH}_{3}\left(\mathrm{CH}_{2}\right)_{5} \mathrm{NH}_{3} \mathrm{SnCl}_{6}$. Spectrochim. Acta, Part A 2001, 57, 2593-2598.

(48) Elleb, M.; Meullemeestre, J.; Schwing-Weill, M. J.; Vierling, F. Stability, electronic spectra, and structure of the copper (II) chloride complexes in N, N-dimethylformamide. Inorg. Chem. 1980, 19, 26992704.

(49) Larentzos, J. P.; Criscenti, L. J. A Molecular Dynamics Study of Alkaline Earth Metal-Chloride Complexation in Aqueous Solution. J. Phys. Chem. B 2008, 112, 14243-14250.

(50) De Robertis, A.; Rigano, C.; Sammartano, S.; Zerbinati, O. Ion association of $\mathrm{Cl}^{-}$with $\mathrm{Na}^{+}, \mathrm{K}^{+}, \mathrm{Mg}^{2+}$ and $\mathrm{Ca}^{2+}$ in aqueous solution at $10 \leqslant \mathrm{~T} \leqslant 45^{\circ} \mathrm{C}$ and $0 \leqslant \mathrm{I} \leqslant 1 \mathrm{~mol} \mathrm{l}^{-1}$ : A literature data analysis. Thermochim. Acta 1987, 115, 241-248.

(51) Friedman, H. L. The Visible and Ultraviolet Absorption Spectrum of the Tetrachloroferrate(III) Ion in Various Medial. J. Am. Chem. Soc. 1952, 74, 5-10.

(52) Khan, M. A.; Meullemeestre, J.; Schwing, M. J.; Vierling, F. Stability, spectra and structure of the copper(II) chloride complexes in acetic acid. Polyhedron 1983, 2, 459-463.

(53) Li, Z.; Bruynseels, B.; Zhang, Z.; Binnemans, K. Separation of $\mathrm{GaCl}_{3}$ from $\mathrm{AlCl}_{3}$ by Solid-Liquid Extraction and Stripping Using Anhydrous n-Dodecane and $\mathrm{NaCl}$. Ind. Eng. Chem. Res. 2019, 58, 12459-12464.

(54) Kloo, L.; Taylor, M. J. Spectroscopic characterisation of indium(III) chloride and mixed ligand complexes. Spectrochim. Acta, Part A 2002, 58, 953-957.

(55) Willey, G. R.; Somasundaram, U.; Errington, W.; Aris, R.; Errington, W. Azamacrocyclic stabilisation of the halogenocations $\mathrm{MX}_{3}{ }^{+}$where $\mathrm{M}=\mathrm{Ge}$ or $\mathrm{Sn}$ and $\mathrm{X}=\mathrm{Cl}$ or Br. Synthesis and molecular structures of $\left[\mathrm{GeCl}_{3}\left(\mathrm{~L}^{1}\right)\right]^{+}{ }_{2}\left[\mathrm{H}_{3} \mathrm{O}\right]^{+} \mathrm{Cl}^{-}{ }_{3} \cdot \mathrm{MeCN}$, $\left[\mathrm{SnCl}_{3}\left(\mathrm{~L}^{1}\right)\right]_{2}^{+}\left[\mathrm{SnCl}_{6}\right]^{2-} \cdot 4 \mathrm{MeCN},\left[\mathrm{GeBr}_{3}\left(\mathrm{~L}^{2}\right)\right]^{+}{ }_{2}\left[\mathrm{MeNH}_{3}\right]^{+} \mathrm{Br}^{-}{ }_{3}$. $\mathrm{MeCN}$ and $\left[\mathrm{SnBr}_{3}\left(\mathrm{~L}^{2}\right)\right]_{2}^{+}\left[\mathrm{SnBr}_{6}\right]^{2-}$ where $\mathrm{L}^{1}=1,4,7$-trimethyl-1,4,7triazacyclononane and $\mathrm{L}^{2}=1,3,5$-trimethyl-1,3,5-triazacyclohexane. J. Chem. Soc., Dalton Trans. 1998, 15, 2573-2576.

(56) Hellman, H.; Laitinen, R. S.; Kaila, L.; Jalonen, J.; Hietapelto, V.; Jokela, J.; Sarpola, A.; Rämö, J. Identification of hydrolysis products of $\mathrm{FeCl}_{3} 6 \mathrm{H}_{2} \mathrm{O}$ by ESI-MS. J. Mass Spectrom. 2006, 41, 1421-1429. 
(57) Lavanant, H.; Virelizier, H.; Hoppilliard, Y. Reduction of copper(II) complexes by electron capture in an electrospray ionization source. J. Am. Soc. Mass Spectrom. 1998, 9, 1217-1221. 